\title{
A Bayesian copula-based spatio-temporal method for multivariate drought risk analysis: A case study of the Balkhash Lake Basin
}

\author{
Xin Yang ${ }^{1}$ and Yongping $\mathrm{Li}^{1}$ \\ ${ }^{1}$ Beijing Normal University
}

July 20, 2021

\begin{abstract}
In this study, a Bayesian copula spatio-temporal drought risk analysis (BCSDA) method is developed through coupling Bayesian copula and spatio-temporal analysis into a general framework. BCSDA can effectively identify drought characteristics and reveal the temporal and spatial variation, as well as analyze drought risk at different guaranteed rates based on the influence of multivariate interaction. Then, BCSDA is applied to the Balkhash Lake Basin (a typical arid watershed in Central Asia) for analyzing drought risk during 1901-2017. Major findings are: (i) Balkhash Lake Basin suffered 53 drought events in 1901-2017, and the most severe drought event occurred in October 1973 to January 1977, which lasted for 40 months and developed into an extreme drought during April 1975 to June 1976, affecting 335,800 square kilometers of the study basin; (ii) most of the drought events developed in the direction of east-west, and Lli River delta and the alluvial plain were the most severe of drought (47.2\%), followed by the plateau desert area (28.3\%) and the arid grassland in north of Balkhash Lake (24.5\%); (iii) drought shows significant seasonality which usually began in spring and summer (64.2\%) and ended in summer and autumn (66.0\%); (iv) in Balkhash Lake Basin, multivariate characteristics (duration, severity and area) would significantly affect drought risk; (v) the range of drought risk would be [1.9\%, 18.1\%], [3.7\%, 33.1\%], [8.7\%, 46.0\%], [16.0\%, 55.1\%] and [27.6\%, 59.8\%] when guarantee rate is $0.99,0.98,0.95,0.90$ and 0.80 .
\end{abstract}

\section{Hosted file}

Manusript for HYP.docx available at https://authorea.com/users/426619/articles/531085-abayesian-copula-based-spatio-temporal-method-for-multivariate-drought-risk-analysis-acase-study-of-the-balkhash-lake-basin

\section{Hosted file}

Cover letter.doc available at https://authorea.com/users/426619/articles/531085-a-bayesiancopula-based-spatio-temporal-method-for-multivariate-drought-risk-analysis-a-case-studyof-the-balkhash-lake-basin 